\title{
Trace element analysis in some Salvia species by inductively coupled plasma-mass spectrometry (ICP-MS) and chemometric approach
}

\author{
Zeki TUNAY 1 (D), İsmail YENER 2 * (D), Elif VARHAN ORAL 2 (D), Aslı Barla DEMIRKOZ 3, 4 (D) Özge \\ TOKUL-ÖLMEZ 5 (D), Mehmet FIRAT 6 (D), Mehmet ÖZTÜRK 5 (D), Işıl AYDIN 2 (D), Furat AYDIN 7 (D), \\ Abdulselam ERTAŞ ${ }^{8}$ (D)
}

1 Dicle University Science and Technology Application and Research Center (DUBTAM), TR-21280 Diyarbakır, Turkey.

2 Department of Analytical Chemistry, Faculty of Pharmacy, Dicle University, TR-21280 Diyarbakır, Turkey.

3 AROMSA A.S, R\&D Center, GOSB Ihsan Dede Cad. 700. Sk. No: 704, TR-41480, Kocaeli, Turkey.

4 Department of Industrial Engineering, Faculty of Engineering, Haliç University, TR-34445, İstanbul, Turkey.

5 Department of Chemistry, Faculty Science, Muğla Sıtkı Koçman University, TR-48121 Muğla, Turkey.

6 Department of Biology, Faculty of Education, Yüzüncü Yıl University, TR-65080 Van, Turkey.

7 Department of Chemistry, Faculty Science, Dicle University, TR-21280 Diyarbakır, Turkey.

8 Department of Pharmacognosy, Faculty of Pharmacy, Dicle University, TR-21280 Diyarbakır, Turkey.

* Corresponding Author. E-mail: ismail.yener@dicle.edu.tr (İ.Y.); Tel. +90-412-248 80 30/7548- +90-554-112 98 18.

Received: 02 December 2019 / Revised: 18 February 2020/ Accepted: 24 February 2020

\begin{abstract}
In this study, the stems, leaves, flowers, roots and mixed all parts of five Salvia species were analyzed for their trace element ( $\mathrm{Li}, \mathrm{Be}, \mathrm{V}, \mathrm{Cr}, \mathrm{Co}, \mathrm{Ni}, \mathrm{Cu}, \mathrm{Zn}, \mathrm{As}, \mathrm{Se}, \mathrm{Rb}, \mathrm{Sr}, \mathrm{Ag}, \mathrm{Cd}, \mathrm{Cs}, \mathrm{Ba}, \mathrm{Hg}, \mathrm{Tl}, \mathrm{Pb}$, and U) contents using ICP-MS. The seeds, roots leaves, flowers, and mixed parts of each species were digested by concentrated nitric acid and hydrogen peroxide in a microwave by before ICP-MS the analysis. The accuracy and precision of the method were evaluated by CRM 1573a Tomato Leaves. Trace element contents in different parts of each sample were compared. Concentration of toxic elements (As, $\mathrm{Cd}, \mathrm{Hg}$ and $\mathrm{Pb}$ ) were lower than those declared by $\mathrm{WHO}$, except $\mathrm{Cr}$ content. Cr content in the root sections of Salvia suffruticosa (SFR), S. hydrangea (SHR), S. trichoclada (STR), S. xanthocheila (SXR), leaf samples of S. kronenburgii (SKL) and S. xanthocheila (SXL). also the Cr content in the leaf sections of Salvia kronenburgii (SKL) Salvia xanthocheila (SXL) was found high. When consider the daily metal (Zn, $\mathrm{Cu}, \mathrm{Sr}, \mathrm{Ba}$ and $\mathrm{Ni}$ ) needs It was concluded that these Salvia species can be nutritive sources. In addition, Salvia samples were classified by utilizing chemometric techniques such as Principal Component Analysis (PCA) and Hierarchical Cluster Analysis (HCA). While the first two main components explained $55.30 \%$ of the total variance, the first six main components explained $89.60 \%$ of total variance
\end{abstract}

KEYWORDS: Salvia, trace element, ICP-MS, PCA.

\section{INTRODUCTION}

Salvia genus a member of the Lamiaceae family grows naturally all over the world with more than 900 species. It is represented, by 89 species and 97 taxa, 45 of which are endemic in Turkish flora [1]. Many of the Lamiaceae species include essential oils which are used in perfumery and pharmaceutical industries [2]. Medicinal plants having biological activity have been used in the treatment of a variety of diseases since ancient times $[3,4]$.

Many Salvia species have been used as tonic and spice and consumed as tea by the local people since ancient times. Salvia species have also been used in the treatment of various diseases [2]. There are many papers show that Salvia species, containing high amount of phenolic compounds, exhibit good antioxidant and antimicrobial activities. Moreover, some were also investigated against various pathological diseases such as atherosclerosis, cerebral function disorders and cancer [5]. These studies showed that some of the Salvia species containing terpenes, phenolics and flavonoids are the resources of homeopathic products [6].

How to cite this article: Tunay Z, Yener I, Varhan Oral E, Barla-Demirkoz A, Tokul-Ölmez O, Fırat M, Öztürk M, Aydın I, Aydın F, Ertaş A. Trace element analysis in some Salvia species by inductively coupled plasma-mass spectrometry (ICP-MS) and chemometric approach. J Res Pharm. 2020; 24(2): 297-309. 
Therefore, most of the species are cultivated because of their medicinal properties [7]. Five Salvia species were studied here that are Salvia suffruticosa, S. hydrangea, S. kronenburgii, Salvia xanthocheila and Salvia trichoclada. The local names of those species are called Çeqlet, Mercanok, Çevrek, Guhbel, and Sevik, respectively [8].

Trace elements play a significant role in the formation of chemical constituents in plants [9]. It is known that twenty-three elements have physiological activities in mammals [10]. Some metals, such as, zinc, iron, copper, chromium and cobalt, are necessary at certain levels and they are toxic in high concentrations. On the other hand, some other metals; namely, mercury, lead and cadmium, are toxic even at low concentrations and have been known no useful properties. Determining of metal ions compositions of plants support their medicinal, nutrient and/or toxic properties [11, 12].

Trace elements have important roles in plant metabolism and biosynthesis as cofactors for the enzymes [13]. Medicinal plants are widely used in the treatment of human diseases and pain relief, due to their low adverse effects. Some medicinal plants and their mixtures may pose health risks owing to toxic elements contain. The contamination may become from environmental pollution [14]. For example, high levels of arsenic can result from the use of pesticides and fertilizers [15]. Human beings need metallic and non-metallic elements, within the permitted limits, for growth and health. Plants are an important medium for trace elements to transit from the soil to human beings [16]. Accordingly, the quality controls of these medicinal plants are important in terms of trace element content.

Graphite furnace atomic absorption spectrometry (GF-AAS) [17], flame atomic absorption spectrometry (F-AAS) [13,18-21], inductively coupled plasma optical emission spectrometry (ICP-OES) [22-24], inductively coupled plasma-mass spectrometry ICP-MS [25-27], techniques are used to determine the trace element contents of medicinal plants. When compared the mentioned techniques, ICP-MS, is a more effective technique in the determination of multiple elements at trace levels due to its high sensitivity, precision and large linear dynamic range.

The most common used chemometric techniques are Principal Component Analysis (PCA) and Hierarchical Clustering Analysis (HCA). PCA seeks for an answer about the relationship between the samples and the interaction between variables. However, Clustering technique (CA) provides information regarding the classification (characterization) of samples. These techniques reveal relationships of classification and the predictions that cannot be considered as "ordinary results"[28, 29].

This paper aims to determine toxic and nutrient elements concentrations of seeds, roots, leaves, flowers, and mixed samples of five Salvia species, collected from Van and Kars using ICP-MS. In addition, classification of trace metal components and evaluation of differences between sections were made by using PCA and HCA methods.

\section{RESULTS AND DISCUSSION}

\subsection{Concentrations of elements in Salvia species}

Seeds, roots, leaves, flowers, and mixed parts of five Salvia species were examined in this study for their metal contents, and the results were presented in Table 1.

The Lithium content was detected in the range of $0.28-11.33 \mathrm{mg} \mathrm{kg}^{-1}$. The Li concentrations in the root samples of SH and also the Li concentrationsin the leaves samples of ST, SX, SK and SF's were higher than other samples. The richest Li content was detected in SX.

The Beryllium and vanadium contents were determined in the range of $2.01-122.16 \mu \mathrm{g} \mathrm{kg}^{-1}$ and $0.15-$ $4.98 \mathrm{mg} \mathrm{kg}^{-1}$, respectively. When compared to other parts, higher Be and V were observed in the roots of SF, SH, SX and ST and leaf of the SK. Among the Salvia species, SX contained the highest Be and V concentration than those of other Salvia species examined.

The Chromium content was detected to be in the range of $0.53-10.09 \mathrm{mg} \mathrm{kg}^{-1}$. When compared to other parts, Cr was observed higher in the roots sections of SF, SH, ST the leaves samples of SK and SX's. Cr contents of the species SX and SF seem to be more than those of other Salvia species examined. The daily intake of chromium varies between 5 and $200 \mathrm{mg} \mathrm{kg}^{-1}$ [30]. In Tokalioglu's study, the $\mathrm{Cr}$ contents in 30 different medicinal herbs samples, consumed around Kayseri city was found to be in the range of $0.44 \mathrm{mg} \mathrm{kg}^{-1}$ (opium poppy) and $8.71 \mathrm{mg} \mathrm{kg}^{-1}$ (nettle) [11]. Abou-Arab and Donia [18] that taken 20 different types of spices and medicinal plant samples from Egypt was founded the $\mathrm{Cr}$ levels in the range of $2.47-33.75 \mathrm{mg} \mathrm{kg}^{-1}$. Also, at the same study Abou-Arab and Donia that taken nine types of medicinal herbs from India was detected the $\mathrm{Cr}$ levels in the range of 0.96-8.19 $\mathrm{mg} \mathrm{kg}^{-1}$ [18]. The limit values for chromium in Canada are determined to be 2 $\mathrm{mg} \mathrm{kg}^{-1}$ and daily intake as $0.02 \mathrm{mg} /$ day [31]. The Cr values in mixed samples of five different Salvia species 
examined in this study, SFM, SHM, SKM, SXM and STM, were found to be $0.76,2.16,4.53,4.65$ and, $3.53 \mu \mathrm{gg}$

1 , respectively. The Cr potential in sage (S. officinalis) in Tokalioglu's [11] study was illustrated as 4.70.

When compared to other parts, more Co was observed in the roots sections of SF, SH and ST, flower section of SX and leaf section of SK, among species examined in this study. Co content of SX seems to be more than those of other Salvia species examined. It is also observed that Ni contents, however, were found to be more in the roots sections of SH and ST, flower section of SX, and leaves sections of SK and SF, when compared to other sections. It can be phrased that Ni content of SX and SK is more than those of other Salvia species examined. Co and Ni values for five different parts of these Salvia species were calculated to be in the range of 0.06-0.96 and 0.86-9.57 $\mathrm{mg} \mathrm{kg}^{-1}$ while those values for mixed samples of five different Salvia species [SFM, SHM, SKM, SXM and STM] were found to be $0.96,0.21,0.42,0.59,0.43 \mathrm{mg} \mathrm{kg}^{-1}$ and 4.57, 1.99, 8.16, 4.05 and $2.70 \mathrm{mg} \mathrm{kg}^{-1}$, respectively. In her study on 30 different medicinal herbs samples, consumed around Kayseri, Turkey, Tokalioglu [11] has reported the Co and Ni values to be in the range of $0.05-2.35 \mathrm{mg} \mathrm{kg}^{-1}$ and $0.72-13.1$ $\mathrm{mg} \mathrm{kg}{ }^{-1}$, respectively. Those values in sage (S. officinalis) sample, however, are reported to be $0.53,3.83 \mathrm{mg} \mathrm{kg}$ ${ }^{1}$. The Co and Ni values in sage sample in Basgel and Erdemoglu [14] were found to be $0.34,2.90 \mathrm{mg} \mathrm{kg}^{-1}$. When compared to other sections, more $\mathrm{Cu}$ was determined in the leaf sections of SF and SK, root sections of SH and ST and stem section of SX among species examined in this present study. Cu content of SX seems to be the lowest of all, but all other Salvia species have close values.

Table 1. Quantification of studied trace elements in Salvia species by ICP-MS.

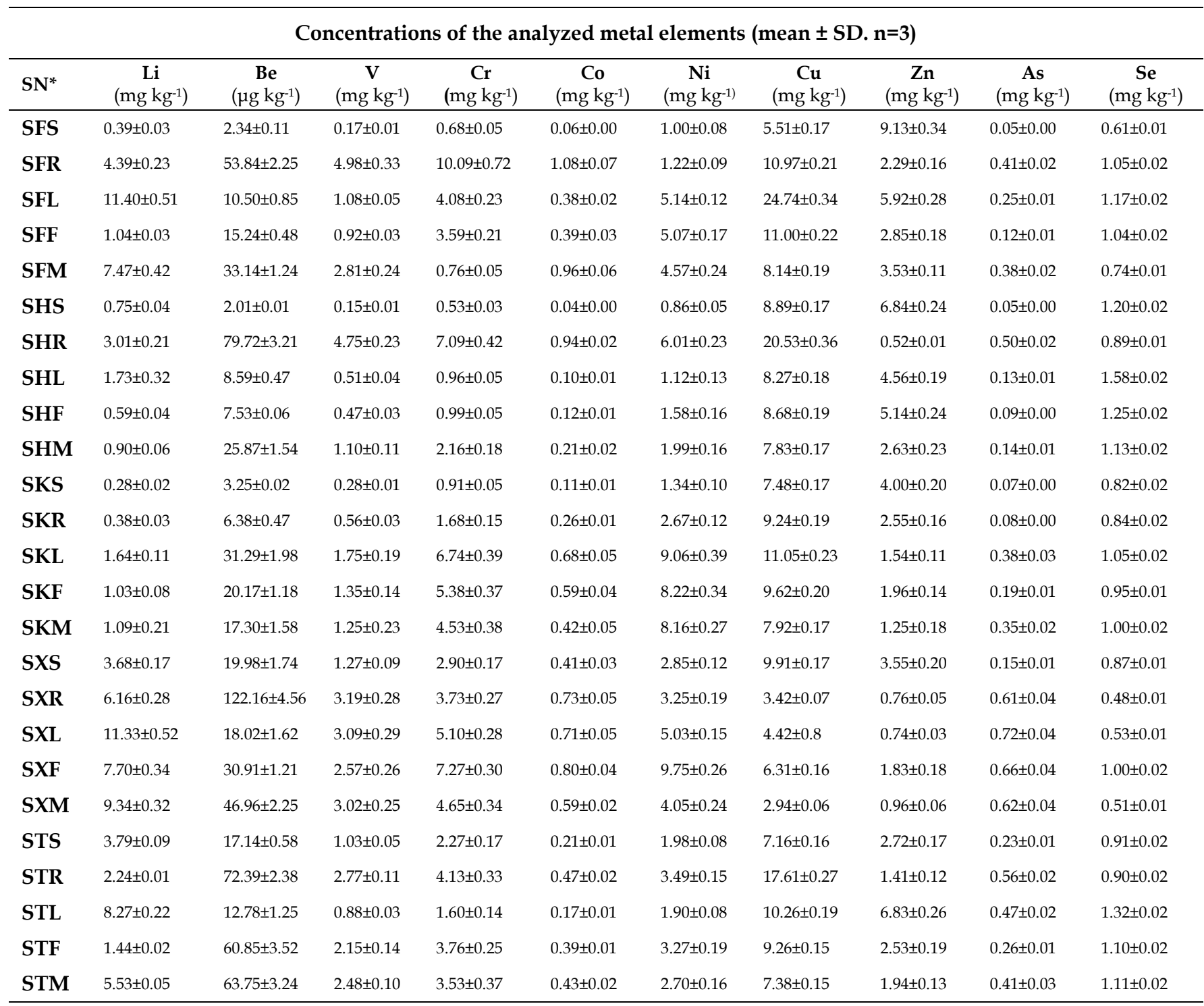


Concentrations of the analyzed metal elements (mean \pm SD $n=3$ )

\begin{tabular}{|c|c|c|c|c|c|c|c|c|c|c|}
\hline $\mathrm{SN}^{*}$ & $\begin{array}{c}\mathbf{R b} \\
\left(\mathrm{mg} \mathrm{kg}^{-1}\right)\end{array}$ & $\begin{array}{c}\mathrm{Sr} \\
\left(\mathrm{mg} \mathrm{kg}^{-1}\right)\end{array}$ & $\begin{array}{c}\text { Ag } \\
\left(\mu \mathrm{kg} \mathrm{kg}^{-1}\right)\end{array}$ & $\begin{array}{c}\text { Cd } \\
\left.(\mu \mathrm{g} \mathrm{kg})^{-1}\right)\end{array}$ & $\begin{array}{c}\text { Cs } \\
\left(\mu \mathrm{g} \mathrm{kg} \mathrm{kg}^{-1}\right)\end{array}$ & $\begin{array}{c}\text { Ba } \\
\left(\mathrm{mg} \mathrm{kg}^{-1}\right)\end{array}$ & $\begin{array}{c}\mathbf{H g} \\
(\mathrm{mg} \mathrm{kg-} \\
1)\end{array}$ & $\begin{array}{c}\text { Tl } \\
\left(\mu \mathrm{kg}^{-1}\right)\end{array}$ & $\begin{array}{c}\mathbf{P b} \\
\left(\mathrm{mg} \mathrm{kg}^{-1}\right)\end{array}$ & $\begin{array}{c}\mathbf{U} \\
(\mu \mathrm{g} \mathrm{kg-1)}\end{array}$ \\
\hline SFS & $2.41 \pm 0.12$ & $60.52 \pm 3.20$ & $20.17 \pm 1.00$ & $4.40 \pm 0.25$ & $2.98 \pm 1.45$ & $50.20 \pm 2.24$ & $0.22 \pm 0.01$ & $1.62 \pm 0.04$ & $0.11 \pm 0.01$ & $2.10 \pm 0.10$ \\
\hline SFR & $3.30 \pm 0.15$ & $311.43 \pm 9.25$ & $44.29 \pm 2.50$ & $34.05 \pm 1.55$ & $94.40 \pm 4.52$ & $\begin{array}{l}153.29 \pm 6.4 \\
8\end{array}$ & $0.50 \pm 0.01$ & $15.92 \pm 0.46$ & $0.61 \pm 0.03$ & $58.53 \pm 2.50$ \\
\hline SFL & $3.75 \pm 0.15$ & $20.24 \pm 1.50$ & $59.64 \pm 3.50$ & $21.30 \pm 1.00$ & $32.45 \pm 1.68$ & $8.79 \pm 0.42$ & $1.51 \pm 0.05$ & $7.80 \pm 0.28$ & $2.94 \pm 0.13$ & $13.63 \pm 1.00$ \\
\hline SFF & $9.02 \pm 0.50$ & $184.29 \pm 5.50$ & $\begin{array}{l}119.05 \pm 6.5 \\
0\end{array}$ & $10.31 \pm 0.50$ & $29.17 \pm 1.15$ & $9.90 \pm 0.46$ & $1.29 \pm 0.05$ & $3.42 \pm 0.18$ & $0.30 \pm 0.01$ & $9.55 \pm 0.50$ \\
\hline SFM & $5.50 \pm 0.25$ & $144.73 \pm 7.25$ & $37.62 \pm 2.50$ & $30.61 \pm 1.85$ & $74.53 \pm 4.52$ & $\begin{array}{l}108.46 \pm 4.2 \\
4\end{array}$ & $0.44 \pm 0.01$ & $15.32 \pm 0.41$ & $0.97 \pm 0.04$ & $33.70 \pm 1.16$ \\
\hline SHS & $9.10 \pm 0.50$ & $\begin{array}{l}202.73 \pm 10.5 \\
0\end{array}$ & $38.00 \pm 2.50$ & $14.55 \pm 0.65$ & $21.10 \pm 1.13$ & $49.00 \pm 2.44$ & $0.24 \pm 0.01$ & $28.31 \pm 0.24$ & $0.40 \pm 0.01$ & $2.11 \pm 0.10$ \\
\hline SHR & $9.95 \pm 0.50$ & $\begin{array}{l}215.32 \pm 10.5 \\
0\end{array}$ & $49.70 \pm 2.50$ & $64.80 \pm 3.34$ & $122.44 \pm 5.89$ & $78.58 \pm 3.45$ & $0.86 \pm 0.03$ & $35.14 \pm 0.26$ & $5.21 \pm 0.26$ & $70.01 \pm 3.25$ \\
\hline SHL & $4.58 \pm 0.20$ & $\begin{array}{l}660.27 \pm 12.2 \\
5\end{array}$ & $32.25 \pm 2.50$ & $15.03 \pm 0.70$ & $21.03 \pm 1.13$ & $79.75 \pm 3.63$ & $0.47 \pm 0.01$ & $22.76 \pm 0.19$ & $0.35 \pm 0.01$ & $7.82 \pm 0.35$ \\
\hline SHM & $7.42 \pm 0.30$ & $\begin{array}{l}193.84 \pm 10.5 \\
0\end{array}$ & $38.90 \pm 3.00$ & $28.42 \pm 1.42$ & $39.37 \pm 1.87$ & $40.15 \pm 2.00$ & $0.64 \pm 0.03$ & $25.12 \pm 0.13$ & $0.62 \pm 0.03$ & $15.28 \pm 0.78$ \\
\hline SKS & $2.22 \pm 0.10$ & $\begin{array}{l}176.06 \pm 10.1 \\
2\end{array}$ & $16.00 \pm 1.00$ & $24.61 \pm 1.27$ & $6.61 \pm 0.28$ & $55.45 \pm 2.63$ & $0.56 \pm 0.01$ & $1.70 \pm 0.14$ & $0.22 \pm 0.01$ & $4.35 \pm 0.20$ \\
\hline SKR & $3.48 \pm 0.05$ & $\begin{array}{l}179.67 \pm 10.2 \\
5\end{array}$ & $28.90 \pm 1.50$ & $32.55 \pm 1.54$ & $12.35 \pm 0.56$ & $55.11 \pm 2.50$ & $1.56 \pm 0.05$ & $2.71 \pm 0.18$ & $0.38 \pm 0.01$ & $7.23 \pm 0.40$ \\
\hline SKL & $5.00 \pm 0.20$ & $\begin{array}{l}454.38 \pm 13.5 \\
0\end{array}$ & $57.64 \pm 2.50$ & $22.15 \pm 1.17$ & $64.22 \pm 3.15$ & $92.23 \pm 3.78$ & $1.04 \pm 0.04$ & $8.06 \pm 0.21$ & $0.60 \pm 0.03$ & $25.72 \pm 1.25$ \\
\hline SKF & $10.47 \pm 0.05$ & $142.56 \pm 7.50$ & $98.40 \pm 5.00$ & $13.00 \pm 0.56$ & $40.95 \pm 2.05$ & $20.25 \pm 1.00$ & $1.13 \pm 0.04$ & $3.67 \pm 0.14$ & $0.68 \pm 0.01$ & $14.02 \pm 0.60$ \\
\hline SKM & $6.67 \pm 0.05$ & $\begin{array}{l}410.56 \pm 15.2 \\
5\end{array}$ & $66.67 \pm 3.50$ & $22.80 \pm 1.16$ & $47.90 \pm 3.27$ & $72.10 \pm 4.85$ & $0.69 \pm 0.02$ & $7.95 \pm 0.28$ & $0.50 \pm 0.05$ & $25.29 \pm 1.50$ \\
\hline SXS & $9.71 \pm 0.50$ & $48.22 \pm 2.25$ & $36.00 \pm 1.80$ & $22.70 \pm 1.17$ & $63.55 \pm 3.27$ & $90.22 \pm 3.85$ & $0.35 \pm 0.01$ & $7.31 \pm 0.34$ & $1.40 \pm 0.10$ & $10.22 \pm 0.65$ \\
\hline SXR & $7.66 \pm 0.35$ & $65.61 \pm 3.50$ & $31.79 \pm 1.50$ & $62.00 \pm 3.21$ & $\begin{array}{l}580.40 \pm 16.7 \\
9\end{array}$ & $\begin{array}{l}181.53 \pm 7.2 \\
5\end{array}$ & $0.15 \pm 0.01$ & $45.39 \pm 0.28$ & $1.97 \pm 0.19$ & $105.60 \pm 4.85$ \\
\hline SXL & $9.91 \pm 0.50$ & $105.85 \pm 4.50$ & $56.50 \pm 2.50$ & $46.10 \pm 2.36$ & $420.36 \pm 8.49$ & $\begin{array}{l}112.80 \pm 4.9 \\
0\end{array}$ & $0.37 \pm 0.01$ & $15.60 \pm 0.65$ & $1.05 \pm 0.09$ & $36.53 \pm 1.85$ \\
\hline SXM & $9.72 \pm 0.50$ & $65.31 \pm 3.50$ & $49.78 \pm 2.50$ & $55.92 \pm 3.47$ & $\begin{array}{l}522.55 \pm 14.6 \\
5\end{array}$ & $\begin{array}{l}125.82 \pm 5.5 \\
0\end{array}$ & $0.26 \pm 0.01$ & $34.90 \pm 0.26$ & $1.50 \pm 0.05$ & $71.80 \pm 3.45$ \\
\hline STS & $4.99 \pm 0.25$ & $30.48 \pm 1.50$ & $63.63 \pm 3.00$ & $21.60 \pm 1.10$ & $47.27 \pm 2.45$ & $27.20 \pm 1.35$ & $0.20 \pm 0.01$ & $8.41 \pm 0.47$ & $0.62 \pm 0.04$ & $33.10 \pm 1.85$ \\
\hline STR & $3.63 \pm 0.05$ & $56.77 \pm 2.50$ & $58.22 \pm 3.00$ & $51.84 \pm 2.58$ & $135.94 \pm 6.75$ & $44.00 \pm 2.12$ & $1.56 \pm 0.06$ & $26.75 \pm 0.20$ & $4.92 \pm 0.02$ & $133.90 \pm 5.25$ \\
\hline STL & $3.55 \pm 0.15$ & $52.65 \pm 2.25$ & $27.88 \pm 1.50$ & $25.42 \pm 1.26$ & $42.10 \pm 2.01$ & $25.64 \pm 1.15$ & $0.61 \pm 0.02$ & $6.22 \pm 0.36$ & $0.51 \pm 0.03$ & $22.91 \pm 1.25$ \\
\hline STF & $8.50 \pm 0.20$ & $13.98 \pm 0.65$ & $\begin{array}{l}120.23 \pm 6.5 \\
0\end{array}$ & $42.43 \pm 2.24$ & $128.45 \pm 5.56$ & $93.01 \pm 3.75$ & $0.81 \pm 0.03$ & $15.00 \pm 0.15$ & $1.09 \pm 0.12$ & $54.83 \pm 2.75$ \\
\hline STM & $4.19 \pm 0.20$ & $46.01 \pm 2.50$ & $62.93 \pm 3.00$ & $49.72 \pm 2.46$ & $101.86 \pm 7.24$ & $28.93 \pm 1.35$ & $0.22 \pm 0.01$ & $20.55 \pm 0.13$ & $1.27 \pm 0.02$ & $69.81 \pm 3.55$ \\
\hline
\end{tabular}

*: Sample Name

When compared to other parts, however, more $\mathrm{Zn}$ content was observed to be in the seeds sections of $\mathrm{SF}, \mathrm{SH}, \mathrm{SK}$ and SX and leaf part of ST, among these species examined in this study. It is apparent that Zn contents of SF and SH samples are more than those of other Salvia species. $\mathrm{Cu}$ and $\mathrm{Zn}$ values for five different parts of these Salvia species were calculated to be in the range of $2.94-24.74$ and $0.52-9.13 \mathrm{mg} \mathrm{kg}^{-1}$ while those values for mixed samples of five different Salvia species [SFM, SHM, SKM, SXM and STM] were found to be $8.14,7.83,7.92,2.94$ and $7.38 \mathrm{mg} \mathrm{kg}^{-1}$ and 3.53, 2.63, 1.25, 0.96, $1.94 \mathrm{mg} \mathrm{kg}^{-1}$, respectively. In her study on 30 different medicinal herbs samples, consumed around Kayseri, Turkey, Tokalioglu [11] has reported the $\mathrm{Cu}$ and $\mathrm{Zn}$ contents to be in the range of 3.32-30.2 $\mathrm{mg} \mathrm{kg}^{-1}$ and 3.75-88-13.1 $\mathrm{mg} \mathrm{kg}^{-1}$, respectively. Those values in sage (S. officinalis) sample, however, are reported to be $6.66 \mathrm{mg} \mathrm{kg}-1$ and $35.8 \mathrm{mg} \mathrm{kg}^{-1}$. The $\mathrm{Cu}$ and $\mathrm{Zn}$ contents in Basgel and Erdemoglu's[14] research on seven different medicinal plants consumed in Turkey are reported as 3.92-35.8 mg kg-1 and 21.9-48.4 mg kg-1. Values in sage sample in Basgel and Erdemoglu[14] additionally, were found to be 35.8 and $48.4 \mathrm{mg} \mathrm{kg}^{-1}$. In another research, Maiga, et. al.[13] was report the $\mathrm{Cu}$ and $\mathrm{Zn}$ values in seven medicinal plants as $2.4-17.1 \mathrm{mg} \mathrm{kg}^{-1}$ and $9.2-67.1 \mathrm{mg} \mathrm{kg}^{-1}$, respectively.

The Arsenic content was determined to be in the range of $0.05-0.72 \mathrm{mg} \mathrm{kg}^{-1}$. When compared to other parts, however, the higher As content was observed to be in the root sections of ST, SF and SH and leaf sections 
of SK and SX, among species examined in this study. The As value of SX seems to be higher than those of other Salvia species.

The Selenium content was determined to be in the range of $0.48-1.58 \mathrm{mg} \mathrm{kg}^{-1}$. In comparison to other parts, however, more Se content was observed to be in the leaf sections of ST, SF, SK and SH and flower section of SX. Se content of SX seems to be the lowest of all, but all other Salvia species have close Se values.

More $\mathrm{Rb}$, when compared to other sections, was determined in flower sections of all Salvia species examined in this study. The content of $\mathrm{Rb}$ for SX appears to be higher than that of other Salvia species. However, Sr contents were determined to be higher in the flower sections of SX, SH and SK, and root sections of ST and SF, in comparison to other sections. In terms of Sr contents, SH has the highest concentration. Sr and $\mathrm{Rb}$ values for five different parts of these Salvia species were calculated to be in the range of 20.24-660.27 $\mathrm{mg} \mathrm{kg}^{-1}$ and 2.22-28.21 mg kg-1 while those values for mixed samples of five different Salvia species [SFM, SHM, SKM, SXM and STM] were found to be 144.73, 193.84, 410.56, 65.31, $46.1 \mathrm{mg} \mathrm{kg}^{-1}$ and 5.50, 7.42, 6.67, $9.72,4.19 \mathrm{mg} \mathrm{kg}^{-1}$, respectively. The Sr contents in the study of Basgel and Erdemoglu's [15] research on seven different medicinal plants consumed in Turkey are reported 16.5- $69.2 \mathrm{~kg}^{-1}$. Values in sage sample in Basgel and Erdemoglu[14], additionally, were found to be $17.5 \mathrm{mg} \mathrm{kg}^{-1}$. The $\mathrm{Sr}$ and $\mathrm{Rb}$ contents in sage (S. officinalis) sample, in Tokalioglu's [11] study on 30 different medicinal herbs samples, consumed around Kayseri, Turkey, were reported to be $46.2 \mathrm{mg} \mathrm{kg}-1$ and $3.67 \mathrm{mg} \mathrm{kg}^{-1}$, respectively.

The Silver content was determined to be in the range of $16.00-120.23 \mu \mathrm{g} \mathrm{kg}-1$. When compared to other parts, more Ag content was observed to be in the flower sections of SF, SK, SX and ST and the root section of $\mathrm{SH}$. The Ag value of SF and ST seems to be higher than those of other Salvia species.

The Cadmium content was determined to be in the range of 4.40-64.80 $\mu \mathrm{g} \mathrm{kg}^{-1}$. When compared to other parts, more Cd content was observed to be in the root sections of all Salvia species. The Cd content of SX and ST appeared to be higher than those of other Salvia species.

The Cesium, tellurium and uranium contents were determined to be in the range of $2.98-580.40 \mu \mathrm{g} \mathrm{kg}^{-1}$, $1.62-45.39 \mu \mathrm{g} \mathrm{kg}^{-1}$ and $2.10-133.90 \mu \mathrm{g} \mathrm{kg}^{-1}$. When compared to other parts, more Cs, $\mathrm{Tl}$ and $\mathrm{U}$ content were observed to be in the root sections of SF, SH, SX and ST and the leaf section of SK. It is observed that Cs content in SX, Tl in SH and U in ST is higher than those of other Salvia species.

The Barium content was determined to be in the range of $8.79-153.29 \mathrm{mg} \mathrm{kg}^{-1}$. When compared to other parts, more Ba content was observed to be in the root sections of SF, SH and SX, leaf section of SK and flower section of ST. The Ba content of SX appeared to be higher than that of other Salvia species.

The Mercury content was determined to be in the range of $0.15-1.56 \mathrm{mg} \mathrm{kg}^{-1}$. When compared to other parts, more Hg content was observed to be in the root sections of ST, SK and SH, leaf section of SF and flower section of SX. The Hg content of SK appeared to be higher than that of other Salvia species.

The Lead content was determined to be in the range of $0.11-5.21 \mathrm{mg} \mathrm{kg}^{-1}$. When compared to other parts, more Ba content was observed to be in the root sections of ST, SX and SH, leaf section of SF and flower section of SK. The Pb content of ST and SH appeared to be higher than that of other Salvia species. Pb values for mixed samples of five different Salvia species we examined in this study [SFM, SHM, SKM, SXM and STM] were found to be $0.97,0.62,0.50,1.50$ and $1.27 \mathrm{mg} \mathrm{kg}^{-1}$, respectively. The Pb value in sage sample in the study of Basgel and Erdemoglu [14] was reported to be $1.14 \mathrm{\mu g} \mathrm{g}^{-1}$ and the Pb value in sage (S. officinalis) sample, in Tokalioglu's[11] study was found to be $1.44 \mathrm{mg} \mathrm{kg}^{-1}$.

Countries in different regions of the world have determined different limits for toxic metals on medicinal plants. For samples of raw herbal materials, the toxicity limits for lead, arsenic, chromium and cadmium are reported to be 10,5, 2 and $0.3 \mathrm{ppm}$, respectively. As for the finished herbal products, the toxicity limits are designated as $0.02 \mathrm{mg} /$ day for lead, chromium and mercury, $0.01 \mathrm{mg} /$ day for arsenic, and 0.006 $\mathrm{mg} /$ day for cadmium [31]. The values for arsenic, lead, cadmium and mercury in all Salvia species examined are lower than the limit values designated for raw herbal materials. The chromium content, however, is higher than $2 \mathrm{mg} \mathrm{kg}^{-1}$, which is the limit value for raw herbal materials. Therefore, it is important to control the dosage of these species in terms of chromium.

The toxicity of metals depends on the oxidation state and concentration. $\mathrm{As}, \mathrm{Cd}, \mathrm{Cr}, \mathrm{Hg}$ and $\mathrm{Pb}$ metals are toxic metals for human beings. While the fact that these toxic metals are generally accumulated at the root sections of Salvia species is an advantage for consumers, it appears that the dosage control of Salvia species in medical use is of paramount importance since the cadmium and lead content in the leaf sections of SF, the 
mercury content in the flower section of SX, the lead content in the flower section of SK are high in comparison to other sections, and these toxic metals exist in every part of Salvia species.

\subsection{Principal Component Analysis (PCA)}

The purpose of the chemometric analysis is to make estimates by reducing the number of dimensions (data) and summarize the data in tables and graphs. In this study, twenty metal contents of five different Salvia species were analyzed. Big data is almost difficult to interpret. For this reason, to decrease the number of data and to turn big data into visual graphics make the interpretation easier. While visualizing all information in the PCA dataset via graphics, the differences between the samples could be detected. At the same time, the graph provides an evaluation of the main components that affect the samples.

PCA results are summarized in Table 2. As a result of principal component analysis performed by twenty heavy metals, 6 components having eigenvalues greater than 1 were obtained. According to the PCA results of Salvia species, the first six principal components explain $89.60 \%$ of the total variance. The first principal component 1 (PC1), second principal component 2 (PC2), third principal component 3 (PC3) and fourth principal component 4 account for $40.3 \%, 15.0 \%, 12.8 \%$ and $9.80 \%$ of total variance, respectively. The percentage for other principal components gradually decreases. Those values which were shown in bold in Table 5 were more effective than others in explaining the principal components. The first principal component indicates the highest variance in the data set. The dominant variables were $\mathrm{Be}, \mathrm{V}, \mathrm{Co}, \mathrm{As}, \mathrm{Cd}$ and $\mathrm{U}$ for PC1, $\mathrm{Cs}$ and $\mathrm{Tl}$ for $\mathrm{PC} 2, \mathrm{Cu}, \mathrm{Hg}$ and $\mathrm{Pb}$ for PC3, Ag for PC4 and $\mathrm{Li}$ and $\mathrm{Zn}$ for PC5.

Table 2. The loading, eigenvalue, variance and cumulative variance data of the principal components analyses (PCA).

\begin{tabular}{ccccccc}
\hline Metal & PC1 & PC2 & PC3 & PC4 & PC5 & PC6 \\
\hline $\mathbf{L i}$ & 0.1761 & 0.0474 & -0.1245 & 0.0328 & $\mathbf{0 . 7 0 0 5}$ & -0.2197 \\
$\mathbf{B e}$ & $\mathbf{0 . 2 9 9 3}$ & 0.0614 & 0.1481 & 0.0632 & -0.2670 & -0.0703 \\
$\mathbf{V}$ & $\mathbf{0 . 3 2 5 2}$ & -0.1129 & 0.0063 & -0.0608 & -0.0013 & -0.0672 \\
$\mathbf{C r}$ & 0.2499 & -0.3597 & -0.1413 & -0.1287 & 0.0250 & 0.0046 \\
$\mathbf{C o}$ & $\mathbf{0 . 2 8 9 2}$ & -0.2627 & -0.1423 & -0.1367 & 0.0251 & 0.0435 \\
$\mathbf{N i}$ & 0.1753 & -0.4259 & -0.2183 & -0.1655 & 0.0257 & 0.0382 \\
$\mathbf{C u}$ & 0.0002 & -0.3074 & $\mathbf{0 . 4 6 3 6}$ & 0.0106 & 0.3006 & -0.0853 \\
$\mathbf{Z n}$ & -0.2766 & 0.0872 & 0.1080 & -0.0507 & $\mathbf{0 . 3 1 4 4}$ & -0.3173 \\
$\mathbf{A s}$ & $\mathbf{0 . 3 1 3 1}$ & -0.0019 & -0.0866 & 0.1546 & 0.0810 & -0.1677 \\
$\mathbf{S e}$ & -0.1908 & -0.2078 & 0.1643 & -0.0596 & -0.1218 & -0.5930 \\
$\mathbf{R b}$ & 0.0113 & -0.0737 & -0.3542 & 0.3101 & -0.0569 & -0.4304 \\
$\mathbf{S r}$ & -0.0558 & -0.1595 & 0.0524 & -0.5557 & -0.2726 & -0.2544 \\
$\mathbf{A g}$ & 0.0495 & -0.3238 & -0.1148 & $\mathbf{0 . 4 6 4 4}$ & -0.2025 & -0.0902 \\
$\mathbf{C d}$ & $\mathbf{0 . 3 0 1 9}$ & 0.1646 & 0.1638 & 0.0820 & -0.0183 & -0.0104 \\
$\mathbf{C s}$ & 0.2729 & $\mathbf{0 . 2 8 2 4}$ & -0.1288 & 0.0565 & 0.0562 & -0.0465 \\
$\mathbf{B a}$ & 0.2182 & 0.1206 & -0.0680 & -0.4756 & 0.1272 & 0.0487 \\
$\mathbf{H g}$ & -0.0382 & -0.3362 & $\mathbf{0 . 3 3 8 7}$ & 0.1342 & 0.0287 & 0.2560 \\
$\mathbf{T l}$ & 0.2115 & $\mathbf{0 . 2 6 9 1}$ & 0.2055 & -0.0682 & -0.2302 & -0.3496 \\
$\mathbf{P b}$ & 0.1991 & -0.0484 & $\mathbf{0 . 4 5 2 9}$ & 0.0924 & 0.1209 & -0.0259 \\
$\mathbf{U}$ & $\mathbf{0 . 2 8 4 9}$ & 0.1067 & 0.2492 & 0.1027 & -0.1371 & 0.0072 \\
Eigenvalue & 8.06 & 3.00 & 2.57 & 1.95 & 1.18 & 1.15 \\
Variance (\%) & 40.30 & 15.00 & 12.80 & 9.80 & 5.90 & 5.70 \\
Cumulative (\%) & 40.30 & 55.30 & 68.20 & 77.90 & 83.80 & 89.60 \\
\hline
\end{tabular}

Table 3 presents the scores of the first sixth rotated principal components for each Salvia sample. When the scores were analysed, it was observed that Be, V, Co, As, Cd and U concentrations were higher in SXR, SHR, SXM, SFR, SXL, STL and SFM while all were lower in SHS, SFS, SHF, SHL, SKS, STS and SFF samples. Similarly, It can be said that Cs and Tl concentrations for the second principal component in SXR and SXM samples are higher when compared to those in other samples. $\mathrm{Cu}, \mathrm{Hg}$ and $\mathrm{Pb}$ concentrations for the PC3 are the highest in STL, SHR and SFL samples, Ag concentration for the PC4 is the highest in STF and SXF samples. The values, which were shown in bold in Table 3 were more effective than others in explaining the score values of the principal components. 
Table 3. The score values of the principle components analyses (PCA).

\begin{tabular}{ccccccc}
\hline Samples & PC1 & PC2 & PC3 & PC4 & PC5 & PC6 \\
\hline SFS & -3.4712 & 1.9264 & -0.7182 & -0.3482 & 0.2001 & 1.9576 \\
SFR & $\mathbf{3 . 2 1 4 3}$ & -2.2246 & -0.7321 & -2.7988 & -0.0205 & -0.1377 \\
SFL & -1.1373 & -1.9946 & $\mathbf{2 . 5 3 6 5}$ & -0.1503 & $\mathbf{3 . 4 3 4 1}$ & -0.6612 \\
SFF & -2.1489 & -1.9508 & -0.3447 & 2.0710 & -0.5420 & 0.8017 \\
SFM & $\mathbf{2 . 1 0 2 3}$ & -0.8462 & -1.3483 & -1.3587 & 0.8893 & 0.7208 \\
SHS & -3.6261 & 1.7021 & 0.3626 & -0.4136 & -0.2579 & -1.4940 \\
SHR & $\mathbf{4 . 4 6 4 4}$ & -1.2280 & $\mathbf{3 . 2 1 0 1}$ & -0.2680 & -0.3274 & -0.3189 \\
SHL & -3.2320 & 0.6651 & 0.8170 & -2.5667 & -1.1988 & -2.1307 \\
SHF & -3.4068 & 0.7904 & -0.5582 & 0.3176 & -0.5564 & -1.7150 \\
SHM & -1.6756 & 0.3900 & 0.6693 & 0.3336 & -1.1917 & -0.1402 \\
SKS & -3.1122 & 1.4001 & 0.0915 & -0.7443 & 0.0434 & 1.5011 \\
SKR & -2.3663 & -0.0117 & 0.7780 & -0.2618 & -0.1559 & 2.0457 \\
SKL & 0.2483 & -2.2055 & -0.2941 & -1.7302 & -0.7851 & 0.3759 \\
SKF & -1.0349 & -2.3969 & -0.8866 & 1.0372 & -0.7454 & 0.8123 \\
SKM & 0.8113 & -2.2015 & -1.1052 & -1.8855 & -1.0238 & 0.2269 \\
SXS & -1.1772 & 0.7053 & -0.3983 & -0.1371 & 0.7757 & 0.4070 \\
SXR & $\mathbf{5 . 7 7 3 5}$ & $\mathbf{3 . 8 1 7 1}$ & -0.0471 & -0.4891 & -0.7920 & -0.0711 \\
SXL & $\mathbf{3 . 1 7 7 2}$ & 1.1953 & -2.1539 & 0.1973 & 1.5494 & 0.3579 \\
SXF & 1.2581 & -2.2017 & -3.6873 & $\mathbf{2 . 3 0 6 4}$ & 0.4109 & -1.6062 \\
SXM & $\mathbf{4 . 2 9 1 5}$ & $\mathbf{2 . 7 6 8 2}$ & -1.1328 & 0.3060 & 0.4905 & -0.0523 \\
STS & -2.5669 & 0.8957 & 0.6258 & 0.2701 & 1.9470 & -0.9534 \\
STR & -1.5429 & 0.9816 & -0.4694 & 0.9531 & 0.0052 & 0.5667 \\
STL & $\mathbf{2 . 9 5 9 8}$ & -0.3487 & $\mathbf{4 . 1 4 0 9}$ & 1.6438 & -0.4327 & 0.5171 \\
STF & 0.5075 & -0.4985 & 0.3856 & $\mathbf{2 . 6 2 0 3}$ & -1.3025 & -0.3483 \\
STM & 1.6899 & 0.8714 & 0.2587 & 1.0958 & -0.4136 & -0.6617 \\
\hline & & & & & & \\
\hline
\end{tabular}

In Figure 1 the score plot graphic was given for Salvia species. SFS, SKS, SHS, STS and SXS samples were significantly separated from the other samples. SHL, SHM and SHF parts of Salvia species, and SKR and STR parts were similar to the stem sections of the other samples, and SFS, SKS, SHS, STS, SXS, SHL, SHM, SHF, SKR and STR samples belong to the same group. In addition, it was also observed that SXR, SXL, SXM and STM set another group. It can also be said that SHS, SHL, SHM and SHF samples of Salvia hydrangea collected from Kars, form another group. SFF, SFL, SKF, SKL, SKM, SXF and STF samples constitute another group, as well. As seen in Figure 1. the flower sections of all Salvia species except SHF, were also in a distinct group. SFM, SFR, SHR and STL were also samples belonging to another group.

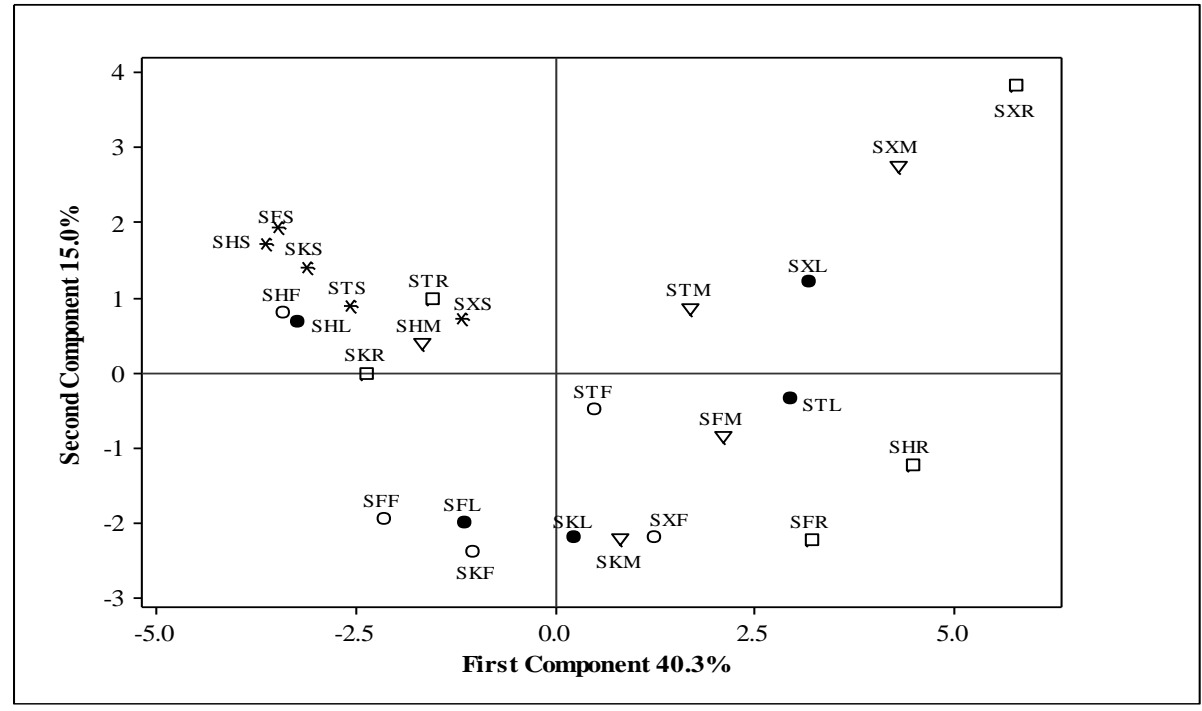

Figure 1. Score plot graphic for principal component analysis (PC1 and PC2) in Salvia species, *stem, $\square$ root, - leaf, o flower and $\nabla$ mixed. 
When Figure 1 and Figure 2 were interpreted together, it was observed that Se and Sr scores of SXR, SXL and SXM samples were low while Tl and Cs scores high. It appears that SXR, SXL and SXM samples provided high correlation with PC2. The stem sections of the samples, however, were not characterized by any heavy metals. SHL, SHF, and SHM samples were characterized by Zn. It was found that, and samples were characterized by and

It was found that SFR, SFF, SFM, SKL, SKF, SKM, SHR, STL and STF samples were characterized by Ni, $\mathrm{Sr}, \mathrm{Cr}, \mathrm{Cu}, \mathrm{Hg}, \mathrm{Ag}, \mathrm{Co}, \mathrm{V}$ and $\mathrm{Rb}$ respectively.

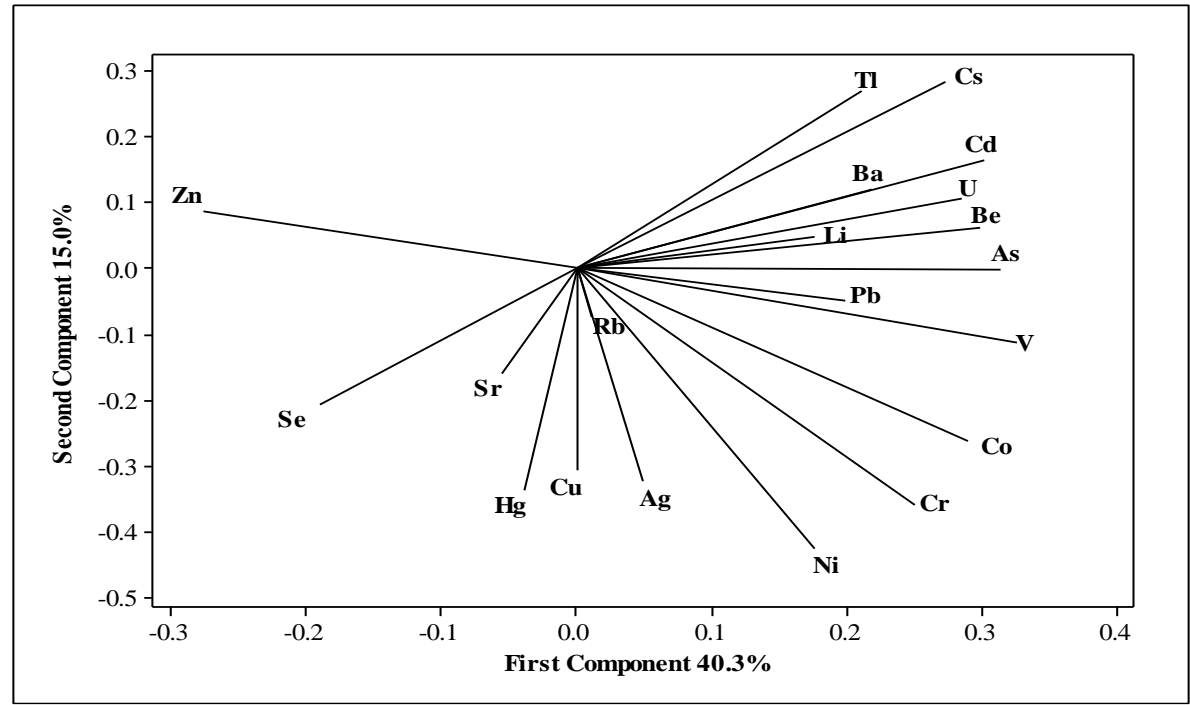

Figure 2. Loading plot for principal component analysis (PC1 and PC2) in Salvia species.

Figure 1 displays the results of cluster analysis (HCA) performed to determine the degree of closeness of Salvia species divided into five different sections. Cluster analysis (HCA) was performed in order to compare the samples taken from two different regions, the distribution of heavy metals in five different sections of these samples and to make comparisons regarding the PCA results. The measurement is based on the Euclidean distance. In this study, The Ward method was used as a clustering method. Dendrogram obtained from the Ward linkage method is shown in Figure 3.

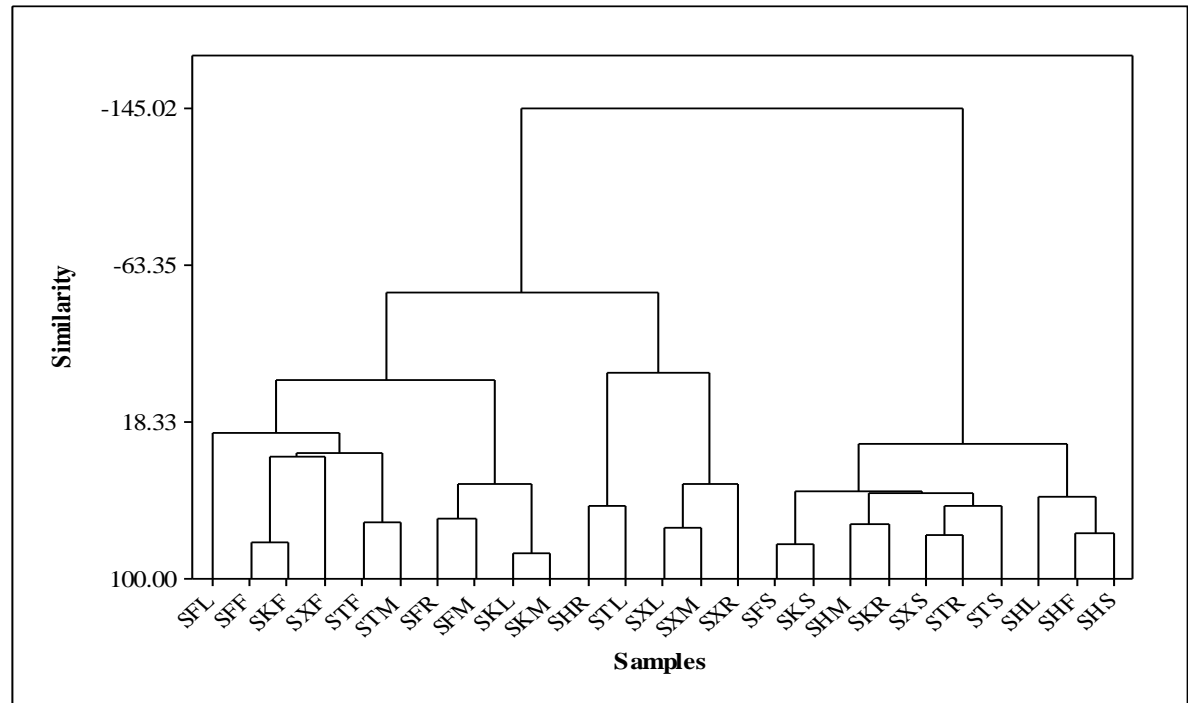

Figure 3. Dendrograms obtained by Euclidean distance and Ward Linkage methods.

When Figure 3 was examined, it was observed that similar results to those of PCA were obtained and five clusters were formed. The first cluster consists of 6 samples; SFF, SKF, SXF and STF samples (flowers) and SFL and STM are included in this group. The second cluster includes 10 samples; these were SFS, SHS, SKS, 
SXS and STS (seeds) samples and SHL, SHM and SHF samples (S. hydrangea) and STR and SKR samples. The third one includes 4 samples, namely SFR, SFM, SKL and SKM samples. Two samples, SHR and STL, are in the fourth cluster. The last cluster was comprised of 3 samples; SXR, SXL and SXM. Cluster 2 samples seemed to be exactly the same as the PCA results.

\section{CONCLUSION}

In this study, twenty ( $\mathrm{Li}, \mathrm{Be}, \mathrm{V}, \mathrm{Cr}, \mathrm{Co}, \mathrm{Ni}, \mathrm{Cu}, \mathrm{Zn}, \mathrm{As}, \mathrm{Se}, \mathrm{Rb}, \mathrm{Sr}, \mathrm{Ag}, \mathrm{Cd}, \mathrm{Cs}, \mathrm{Ba}, \mathrm{Hg}, \mathrm{Tl}, \mathrm{Pb}$, and $\mathrm{U}$ ) trace elements contents of five $\mathrm{S}$. species, collected from the Van and Kars cities in Turkey, were investigated for the first time. Since S. species are consumed as herbal tea and medicinal plants by the people, it is important to determine the trace element content from the point of consumers. ICP-MS technique, used in trace element analysis after microwave digestion, is a fast, accurate, precise and sensitive method.

The toxicity of metals depends on the oxidation state and concentration. $\mathrm{As}, \mathrm{Cd}, \mathrm{Cr}, \mathrm{Hg}$ and $\mathrm{Pb}$ metals are toxic metals for human beings. In our study, the values for lead, arsenic, and cadmium in all Salvia species examined are lower than the toxicity limit values designated for raw herbal materials $(10,5$ and 0,3 ppm, respectively). Our results show that, toxic metals are generally accumulated in the plants' root sections, while the fact that these toxic metals are generally accumulated at the root sections of Salvia species is an advantage for consumers, it appears that the dosage control of Salvia species in medical use is of paramount. Also the cadmium and lead content in the leaf sections of SF, the mercury content in the flower section of SX, the lead content in the flower section of SK are high in comparison to other sections. When the stem, leaves, flower, root and mixed sections of Salvia species examined in this study were analyzed, as seen that the content of chromium in some parts is higher than $2 \mathrm{mg} \mathrm{kg}^{-1}$, which is the limit value for raw herbal materials. Therefore, it is important to control the dosage of these species in terms of chromium.

And all the studied Salvia species are illustrated to be resources to meet the amount of nutritive element requirements to be taken on a daily basis (the daily requirements of a person weighing $70 \mathrm{~kg}$ have been detected for $\mathrm{Zn}$ (15 mg/day), Cu (2.5 mg/day), Sr (1.6 mg/day) and $\mathrm{Ni}(0.025 \mathrm{mg} /$ day) ).

Considering all the results, it is concluded that these Salvia species can be consumed as medicinal plants and herbal tea provided that dose control.

The first two components in PCA performed for Salvia species and sections were sufficient to explain $55.30 \%$ of the total variance. According to the PCA results, the root sections of SH, ST, SX, SK and SF samples emerged in a factor and SHL, SHM, SHF, SKR and STR samples were similar to this group. HCA also supported these findings. It was observed that the Zn content of species in this group was higher than other samples. Other heavy metal concentrations were found to be much lower. It can also be inferred that the flower sections of ST, SX, SK and SF samples were clustered in a group and the leaf section of SF sample appears to be similar to this cluster. The leaf, root and mixed sections of SX sample were also included in a single cluster. The mixed section of ST is similar to that cluster. Cs and Tl elements are heavy metals which affect this group most. Similar findings were obtained as results of PCA and HCA.

\section{MATERIALS AND METHODS}

\subsection{The plant materials}

The aerial parts and roots (whole Salvia species) of S. suffruticosa, S. hydrangea, S. kronenburgii, S. xanthocheila and S. trichoclada were collected from southeastern Turkey (Gurpinar, Van; Kagizman, Kars; Gurpinar, Van; Gurpınar, Van and Catak, Van; respectively) in July 2014, and identified by M. Firat. Voucher specimens were deposited in the Herbarium of Van Yuzuncu Yil University, Faculty of Education (Table 4.).

\subsection{Instruments}

An Agilent 7700X ICP-MS (Tokyo, Japan) was used to determine As, Ag, Ba, Be, Cd, Co, Cr, Cu, Cs, Hg, $\mathrm{Li}, \mathrm{Na}, \mathrm{Pb}, \mathrm{Rb}, \mathrm{Se}, \mathrm{Sr}, \mathrm{Tl}, \mathrm{U}, \mathrm{V}$, and $\mathrm{Zn}$ in the samples. Digestion procedure of the studied samples prior to analysis was carried out in a Milestone Start D Brand microwave (Denmark) oven equipped with PTFE vessels.

\subsection{Reagents and solutions}

For analytical purity was used ultra-pure nitric acid (Merck, Darmstadt, Germany) and ultra-pure hydrogen peroxide (Merck, Darmstadt, Germany). Ultrapure deionized water (18,2 M $\Omega$ ) was used in all experiments. In the ICP-MS measurements were used ${ }^{45} \mathrm{Sc},{ }^{72} \mathrm{Ge},{ }^{115} \mathrm{In}$ and ${ }^{209} \mathrm{Bi}$ at $200 \mu \mathrm{g} \mathrm{L} \mathrm{L}^{-1}$ concentration as mixed internal standards. After diluted at $10 \mathrm{mg} \mathrm{L}^{-1} \mathrm{mix}$ standard in the concentration range of $0-100 \mu \mathrm{g} \mathrm{L}^{-1}$, 
the calibration curves were prepared for $\mathrm{As}, \mathrm{Ag}, \mathrm{Ba}, \mathrm{Be}, \mathrm{Cd}, \mathrm{Co}, \mathrm{Cr}, \mathrm{Cu}, \mathrm{Cs}, \mathrm{Hg}, \mathrm{Li}, \mathrm{Ni}, \mathrm{Pb}, \mathrm{Rb}, \mathrm{Se}, \mathrm{Sr}, \mathrm{Tl}, \mathrm{U}, \mathrm{V}$, and $\mathrm{Zn}$ metals. Internal and calibration standards were obtained from Agilent Technologies (USA). The accuracy and precision of the method were evaluated by using a CRM NIST 1573a Tomato Leaves (National Institute of Standards and Technology, NIST, Gaithersburg, MD, USA) Certified Standard Reference Material.

Table 4. Information about of studied Salvia species.

\begin{tabular}{|c|c|c|c|c|}
\hline Sample names & $\begin{array}{c}\text { Sample } \\
\text { abbreviations }\end{array}$ & $\begin{array}{c}\text { Collection } \\
\text { location }\end{array}$ & $\begin{array}{c}\text { Collection } \\
\text { time }\end{array}$ & $\begin{array}{c}\text { Herbarium } \\
\text { number }\end{array}$ \\
\hline Salvia suffruticosa seed & SFS & & & \\
\hline Salvia suffruticosa root & SFR & & & \\
\hline Salvia suffruticosa leaf & SFL & & & \\
\hline Salvia suffruticosa flower & SFF & & & \\
\hline Salvia suffruticosa mixed & SFM & Gurpinar Van & July 2014 & VANF-164079 \\
\hline Salvia hydrangea seed & SHS & & & \\
\hline Salvia hydrangea root & SHR & & & \\
\hline Salvia hydrangea leaf & SHL & & & \\
\hline Salvia hydrangea flower & SHF & & & \\
\hline Salvia hydrangea mixed & SHM & Kagizman Kars & July 2014 & VANF-164080 \\
\hline Salvia kronenburgii seed & SKS & & & \\
\hline Salvia kronenburgii root & SKR & & & \\
\hline Salvia kronenburgii leaf & SKL & & & \\
\hline Salvia kronenburgii flower & SKF & & & \\
\hline Salvia kronenburgii mixed & SKM & Gurpinar Van & July 2014 & VANF-164081 \\
\hline Salvia xanthocheila seed & SXS & & & \\
\hline Salvia xanthocheila root & SXR & & & \\
\hline Salvia xanthocheila leaf & SXL & & & \\
\hline Salvia xanthocheila flower & SXF & & & \\
\hline Salvia xanthocheila mixed & SXM & Gurpinar Van & July 2014 & VANF-164082 \\
\hline Salvia trichoclada seed & STS & & & \\
\hline Salvia trichoclada root & STR & & & \\
\hline Salvia trichoclada leaf & STL & & & \\
\hline Salvia trichoclada flower & STF & & & \\
\hline Salvia trichoclada mixed & STM & Catak Van & July 2014 & VANF-164083 \\
\hline
\end{tabular}

\subsection{Sample preparation}

The studied Salvia species were divided into groups as seeda, roots, leaves, flowers and mixed, washed by tap water first and deionized water secondly, and dried at $70{ }^{\circ} \mathrm{C}^{\prime}$ for 48 hours. Parts of the species were coded as S. suffruticosa (SF), S. hydrangea (SH), S. kronenburgii (SK), S. xanthocheila (SX) and S. trichoclada (ST). Additionally, the seed, root, leaf, flower and mixed groups were encoded as (S), (R), (L), (F) and (M) respectively. Then, the dried Salvia species were pulverized by a blender. About $200 \mathrm{mg}$ of pulverized samples were accurately weighed into PTFE digestion vessels and $6 \mathrm{~mL} \mathrm{HNO}_{3}$ and $2 \mathrm{~mL} \mathrm{H}_{2} \mathrm{O}_{2}$ were added; then, they were digested in a microwave oven. The digested samples were taken into $25 \mathrm{~mL}$ volumetric flasks and filled by deionized water. Blank tests were carried out as three independent experiments in the same way. The certified standard reference material CRM 1573a Tomato Leaves (National Institute of Standards and Technology, NIST, Gaithersburg, MD, USA) was applied for the same digestion method mentioned above.

\subsection{Method validation}

Linear range, regression correlation coefficient (R), LOD and LOQ values regarding the calibration curve drawn for twenty elements under optimized working conditions are presented in Table 5 . The fact that $r^{2}$ value appears to be higher than 0.99 indicate that linearity is acceptable. The limits of detection and quantification for the metals were calculated using standard deviation ( $\left.\sigma_{\text {blank}}\right)$ of 10 independent blank solutions and the slope $(\mathrm{m})$ of the calibration graph to obtain $\mathrm{LOD}$ or $\mathrm{LOQ}=\mathrm{ax}(\mathrm{\sigma} / \mathrm{m})$; where a is equal to 3 for the LOD and 10 for the LOQ (Table 5). 
Table 5. Analytical parameters of the applied ICP-MS method used to quantify the trace elements in Salvi species (linear range. regression correlation coefficient (R). limit of detection (LOD) and limit of quantification (LOQ)).

\begin{tabular}{|c|c|c|c|c|c|}
\hline Element & $\begin{array}{l}\text { Linear range } \\
\left(\mu \mathrm{kg}^{-1}\right)\end{array}$ & Regression & $\begin{array}{l}\text { Correlation } \\
\text { coefficient }(r)\end{array}$ & $\begin{array}{c}\text { Limit of } \\
\text { detection }(\mu \mathrm{g} \\
\left.\mathrm{kg}^{-1}\right)\end{array}$ & $\begin{array}{c}\text { Limit of } \\
\text { quantification }(\mu \mathrm{g} \\
\left.\mathrm{kg}^{-1}\right)\end{array}$ \\
\hline $\mathrm{Ag}$ & $1-100$ & $y=0.4710 x-2.2430$ & 0.9890 & 0.2356 & 0.7068 \\
\hline As & $1-100$ & $y=0.0783 x+0.1780$ & 0.9901 & 0.1070 & 0.3210 \\
\hline $\mathrm{Ba}$ & $1-100$ & $y=0.0121 x+0.0130$ & 0.9993 & 0.2249 & 0.7489 \\
\hline $\mathrm{Be}$ & $1-100$ & $y=0.0246 x+0.1692$ & 0.9909 & 0.0213 & 0.0639 \\
\hline $\mathrm{Cd}$ & $1-100$ & $y=0.0334 x+0.0290$ & 0.9963 & 0.0132 & 0.0396 \\
\hline $\mathrm{Co}$ & $1-100$ & $y=0.1219 x+0.0901$ & 0.9907 & 0.2202 & 0.6606 \\
\hline $\mathrm{Cr}$ & $1-100$ & $y=0.1028 x+0.3012$ & 0.9989 & 0.2175 & 0.6525 \\
\hline Cs & $1-100$ & $y=0.0480 x-0.0168$ & 0.9895 & 0.0310 & 0.0930 \\
\hline $\mathrm{Cu}$ & $1-100$ & $y=0.0658 x+0.1028$ & 0.9999 & 0.0200 & 0.0600 \\
\hline $\mathrm{Hg}$ & $1-100$ & $y=0.0111 x-0.0124$ & 0.9860 & 0.0543 & 0.1629 \\
\hline $\mathrm{Li}$ & $1-100$ & $y=0.1057 x-0.0442$ & 0.9989 & 0.1216 & 0.3648 \\
\hline $\mathrm{Ni}$ & $1-100$ & $y=0.0277 x+0.0370$ & 0.9999 & 0.3108 & 0.9324 \\
\hline $\mathrm{Pb}$ & $1-100$ & $y=0.1860 x+0.2304$ & 0.9936 & 0.0832 & 0.2777 \\
\hline $\mathrm{Rb}$ & $1-100$ & $y=0.1290 x+0.1301$ & 0.9891 & 0.2873 & 0.8634 \\
\hline Se & $1-100$ & $y=0.0025 x+0.0070$ & 0.9940 & 0.2321 & 0.6963 \\
\hline $\mathrm{Sr}$ & $1-100$ & $y=0.1912 x+0.4047$ & 0.9912 & 0.0896 & 0.2688 \\
\hline $\mathrm{Tl}$ & $1-100$ & $y=0.1379 x-0.1230$ & 0.9991 & 0.2551 & 2.7653 \\
\hline $\mathrm{U}$ & $1-100$ & $y=0.1530 x+0.0646$ & 0.9898 & 0.0044 & 0.0146 \\
\hline $\mathrm{V}$ & $1-100$ & $y=0.1221 x+0.0849$ & 0.9992 & 0.2770 & 0.8310 \\
\hline $\mathrm{Zn}$ & $1-100$ & $y=0.0717 x+0.1806$ & 0.9966 & 0.3085 & 0.9255 \\
\hline
\end{tabular}

Findings regarding the certified standard reference material CRM NIST 1573a Tomato Leaves (National Institute of Standards and Technology, Gaithersburg, MD, USA) analyzed to evaluate the accuracy and precision of the method are presented in Table 6.

Table 6. Accuracy assessment of analysis of CRM NIST1573a Tomato Leaves.

\begin{tabular}{cccc}
\hline Elements & Certified $(\mathbf{m g} / \mathbf{k g})$ & Found $(\mathbf{m g} / \mathbf{k g})$ & Recovery $(\%)$ \\
\hline $\mathrm{As}$ & $0.122 \pm 0.004$ & $0.128 \pm 0.005$ & 104 \\
$\mathrm{Ba}$ & $63 \pm 2$ & $64 \pm 1$ & 102 \\
$\mathrm{Cr}$ & $1.99 \pm 0.06$ & $2.00 \pm 0.07$ & 100 \\
$\mathrm{Cd}$ & $1.52 \pm 0.04$ & $1.49 \pm 0.04$ & 98 \\
$\mathrm{Co}$ & $0.57 \pm 0.02$ & $0.56 \pm 0.06$ & 98 \\
$\mathrm{Cu}$ & $4.70 \pm 0.14$ & $4.76 \pm 0.08$ & 101 \\
$\mathrm{Fe}$ & $368 \pm 7$ & $375 \pm 6$ & 102 \\
$\mathrm{Hg}$ & $0.034 \pm 0.004$ & $0.032 \pm 0.003$ & 94 \\
$\mathrm{Ni}$ & $1.59 \pm 0.07$ & $1.57 \pm 0.11$ & 99 \\
$\mathrm{Rb}$ & $14.89 \pm 0.27$ & $15.19 \pm$ & 102 \\
$\mathrm{Se}$ & $0.054 \pm 0.003$ & $0.051 \pm 0.003$ & 94 \\
$\mathrm{U}$ & $(0.035)^{\mathrm{a}}$ & $0.034 \pm 0.001$ & 97 \\
$\mathrm{~V}$ & $0.835 \pm 0.010$ & $0.826 \pm 0.008$ & 99 \\
$\mathrm{Zn}$ & $30.9 \pm 0.7$ & $31.3 \pm 0.2$ & 101 \\
\hline
\end{tabular}

a:Values in parentheses are not certified values, Values expressed are means \pm standard deviation of three parallel measurements $(p<0.05)$.

\subsection{The chemometric analysis}

The chemometric analyses of metal contents of seeds, roots, leaves, flowers and mixed parts of five Salvia species were carried out using principal component analysis (PCA) and hierarchical clustering analysis 
(HCA), which are multivariate data analysis methods. Both methods for clustering and classification are mainly based upon the principal component analysis. PCA reduces multiple variables into a set of fewer components created by their linear combinations by hindering correlations between those examined variables. PCA-based methods can classify the samples by clustering into various groups. HCA classifies samples in a given data set and defines those data according to their similarities. HCA can be applied directly to the original variables, as well as possible to be applied to the results obtained from PCA, in case of existing too many variables. In this study, HCA applied to the results of the analysis of trace metal components, the measurement is based on the Euclidean distance. The Ward's method was used as a clustering method. In this context, all classification and clustering analyses for Salvia species were carried out using Minitab statistical software.

\subsection{Statistical Method}

All statistical calculations were made using Minitab 16.2.1 statistical software (Minitab Inc. 2010). In this study the sections (seeds, leaves, flowers, roots and mixed) of the five Salvia species were classified multivariate analysis regarding twenty trace metal components in Salvia species were carried out using PCA and HCA techniques.

Acknowledgements: The research was supported by grant: ECZACILIK 17. 002 from Dicle University

Author contributions Concept - I.Y., M.O., F.A., A.S; Design - I.Y., M.O., F.A., A.S.; Supervision - I.Y., E.V.O. A.S.; Resources - Z.T., E.V.O., A.B.D., M.F., I.A., F.A.; Materials -; Data Collection and/or Processing -I.Y., E.V.O., A.B.D., O.T.O., M.F., İ.A., A.S.; Analysis and/or Interpretation - I.Y., Z.T., E.V.O., O.T.O., M.Ö., İ.A.; Literature Search - I.Y., Z.T., E.V.O., A.B.D., M.F.; Writing - I.Y., E.V.O., M.Ö., O.T.O., A.S; Critical Reviews - Z.T., İY., E.V.O., A.B.D., O.T.O., M.F., M.Ö., I.A., F.A., A.S.

Conflict of interest statement: The authors declare no competing financial interest

\section{REFERENCES}

[1] Guner A, Ozhatay N, Ekim T, Baser KHC. Flora of Turkey and the East Aegean Islands 11. Edinburgh, Edinburgh University Press, UK 2000.

[2] Baytop T. Tükçe Bitki Adları Sözlüğü/ Dictionary of Plant Names in Turkish. Türk Tarih Kurumu Basımevi, Ankara 1994.

[3] Ertas A, Boga M, Hasimi N, Yilmaz MA. Fatty acid and essential oil compositions of Trifolium angustifoliumvar. angustifoliumwith antioxidant, anticholinesterase and antimicrobialactivities. Iran J Pharm Sci. 2015a; 14(1): $233-241$.

[4] Ertas A, Boga, M, Yilmaz MA, Yesil Y, Temel H, Hasimi N, Gazioglu I, Ozturk M, Ugurlu P. A detailed study on the chemical and biological profiles of essential oil and methanol extract of Thymus nummularius (Anzer tea): Rosmarinic acid. Ind Crops Prod. 2015b; 67: 336-345. [CrossRef]

[5] Martinez-Cruz O, Paredes-Lopez O. Phytochemical profile and nutraceutical potential of chia seeds (Salvia hispanica L.) by ultra-high performance liquid chromatography. J Chromatogr A. 2014; 1346: 43-48. [CrossRef]

[6] Erdoğan-Orhan I, Sezer-Senol F, Ozturk N, Akaydin G, Sener B. Profiling of in vitro neurobiological effects and phenolic acids of selected endemic Salvia species. Food Chem. 2012; 132(3): 1360-1367. [CrossRef]

[7] Topçu G, Ertas A, Kolak U, Ozturk M, Ulubelen A. Antioxidant activity tests on novel triterpenoids from Salvia macrochlamys. Arkivoc. 2007; 7: 195-208.

[8] Fırat M. Ferhenga Navên Riwekên Bi Kurdî/Kürtçe Bitki Adları Sözlüğü/ Dictionary of Plant Names in Kurdish. Kalkan Ofset. Ankara 2013.

[9] Abugassa IO, Bashir AT, Doubali K, Etwir RH, Abu-Enawel M, Abugassa SO. Characterization of trace elements in medicinal herbs by instrumental neutron activation analysis. J Radioanal Nucl Chem. 2008; 278: 559-563. [CrossRef]

[10] Karadas C, Kara D. Chemometric approach to evaluate trace metal concentrations in some spices and herbs. Food Chem. 2012; 130: 196-202. [CrossRef]

[11] Tokalioglu S. Determination of trace elements in commonly consumed medicinal herbs by ICP-MS and multivariate analysis. Food Chem. 2012; 134: 2504-2508. [CrossRef]

[12] Klaric DA, Klaric I, Mornar A, Velic D, Velic, N. Blackberry wines mineral and heavy metal content determination after dry ashing: multivariate data analysis as a tool for fruit wine quality control. Int J Food Sci Nutr. 2016; 67(5): 514-523. [CrossRef] 
[13] Maiga A, Diallo D, Bye R. Paulsen BS. Determination of some toxic and essential metal ions in medicinal and edible plants from Mali. J Agr Food Chem. 2005; 53: 2316-2321. [CrossRef]

[14] Basgel S, Erdemoglu SB. Determination of mineral and trace elements in some medicinal herbs and their infusions consumed in Turkey. Sci Total Environ. 2006; 359: 82-89. [CrossRef]

[15] Giacomino A, Abollino O, Casanova C, La Gioia C, Magi E, Malandrino M. Determination of the total and bioaccessible contents of essential and potentially toxic elements in ayurvedic formulations purchased from different commercial channels. Microchem J. 2015; 120: 6-17. [CrossRef]

[16] Bin C, Xiaouru W, Lee FSC. Pyrolysis coupled with atomi absorption spectrometry for determination of mercury in Chinese medicinal materials. Anal Chim Acta. 2001; 447: 161-9. [CrossRef]

[17] Sołtyk K, Fijałek Z. Inductively-coupled plasma mass spectrometric (ICP-MS) and graphite-furnace atomic absorption spectrometric (GF-AAS) determinations of arsenic, cadmium and lead impurities in medicinal herbal raw materials. Chem Anal. 2000; 45: 879-886.

[18] Abou-Arab AAK, Abou Donia MA. Heavy metals in Egyptian spices and medicinal plants and the effect of processing on their levels. J Agr Food Chem. 2000; 48(6): 2300-2304. [CrossRef]

[19] Chizzola R, Michitsch H, Franz C. Monitoring of metallic micronutrients and heavy metals in herbs, spices and medicinal plants from Austria. Eur Food Res Technol. 2003; 216: 407-411. [CrossRef]

[20] Mendil D, Karatas M, Tuzen M. Separation and preconcentration of $\mathrm{Cu}$ (II), $\mathrm{Pb}$ (II), $\mathrm{Zn}$ (II), $\mathrm{Fe}(\mathrm{III})$ and $\mathrm{Cr}$ (III) ions with coprecipitation method without carrier element and their determination in food and water samples. Food Chem. 2015; 177: 320-324. [CrossRef]

[21] Szymczycha-Madeja A, Welna M, Pohl P. Comparison and Validation of Different Alternative Sample Preparation Procedures of Tea Infusions Prior to Their Multi-Element Analysis by FAAS and ICP OES. Food Anal Methods. 2016; 9: 1398-1411. [CrossRef]

[22] Shen $Y$, Zheng C, Jiang X, Wu X, Hou X. Integration of hydride generation and photochemical vapor generation for multi-element analysis of traditional Chinese medicine by ICP-OES. Microchem J. 2015; 123: 164-169. [CrossRef]

[23] Szymczycha-Madeja A, Welna M, Pohl P. Determination of essential and non-essential elements in green and black teas by FAAS and ICP-OES simplified-multivariate classification of different tea products. Microchem J. 2015; 121: 122-129. [CrossRef]

[24] AL-Oud SS. Heavy metal contents in tea and herb leaves. Pak J Biol Sci. 2003; 6(3): 208-212.

[25] Nookabkaew S, Rangkadilok N, Satayavivad J. Determination of trace elements in herbal tea products and their infusions consumed in Thailand. J Agr Food Chem. 2006; 54: 6939-6944. [CrossRef]

[26] Bora T, Aksoy C, Tunay Z, Aydın F. Determination of trace elements in illicit spice samples by using ICP-MS. Microchem J. 2015, 123, 179-184. [CrossRef]

[27] Nia Z, Zhenchao C, Ruiliang B, Fubin T. Determination of Trace Elements in Dendrobium Officinale Cultivated in Various Conditions. Anal Lett. 2018; 51 (5): 648-658. [CrossRef]

[28] Diraman H, Cam M, Ozder Y. Yabancı Ülke Kökenli Natürel Zeytinyağlarının Yağ Asitleri ve Triaçilgliserol Bileşenlerine Göre Kemometrik Sınıflandırılması, Gıda Teknolojileri Elektronik Dergisi, Cilt: 4, No: 2:22-34, 2009.

[29] Vlaisavljevic S, Martinez MC, Stojanovic A, Martinez-Huelamo M, Grung B, Raventos RML. Characterisation of bioactive compounds and assessment of antioxidant activity of different traditional Lycopersicum esculentum L. varieties: chemometric analysis. Int J Food Sci Nutr. 2019; 70(7): 813-824. [CrossRef]

[30] Belitz H, Grosch W, Schieberle P. Food Chemistry (3rd ed.) Springer, Berlin 2009.

[31] WHO. International Programme On Chemical Safety. Assessing Human Health Risks of Chemicals: Derivation Of Guidance Values For Health-Based Exposure Limits. World Health Organization, (Environmental Health Criteria 170), Geneva 1994. 